\title{
The Relationship between Traditional Ecological Knowledge, Evolving Cultures, and Wilderness Protection in the Circumpolar North
}

\author{
$\underline{\text { Alan Watson }^{1}}, \underline{\text { Lilian Alessa }}$, and Brian Glaspell
}

\begin{abstract}
There are many unique issues associated with natural resource management in the far north as a result of legislative direction, historic settlement and occupation patterns, northern cultural traditions, ecotourism, economic depression, pressures for energy development, and globalization and modernization effects. Wilderness designation in Canada, the USA, and Finland is aimed at preserving and restoring many human and ecological values, as are the long-established, strictly enforced, nature reserves in Russia. In Alaska and Finland, and in some provinces of Canada, there is a variety of values associated with protecting relatively intact relationships between indigenous people and relatively pristine, vast ecosystems. These values are often described as "traditional means of livelihood," "traditional means of access," "traditional relationships with nature," or "traditional lifestyles." Traditional ecological knowledge (TEK) forms part of these relationships and has been acknowledged as a contributor to understanding the effects of management decisions and human-use impacts on long-term ecological composition, structure, and function. Wilderness protection can help maintain opportunities to continue traditional relationships with nature. As cultures continue to evolve in customs, attitudes, knowledge, and technological uses, values associated with both TEK and relationships with relatively pristine ecosystems will also evolve. Understanding these relationships and how to consider them in wilderness protection and restoration decision making is potentially one of the most contentious, widespread natural resource management issues in the circumpolar north.
\end{abstract}

\section{INTRODUCTION}

Although the U. S. National Wilderness Preservation System was created in 1964, the intentions of the people who negotiated the enactment of this law are still open to interpretation (Cole 2000, Landres et al. 2000). Initially, recreation values were very important in deciding which areas to protect as wilderness, but protecting intact ecosystems and nature restoration have become increasingly acknowledged as important functions of places to include in this national system. Finland and Canada have also established wilderness protection through legislation and zoning (Martin and Watson 2002). Some of Russia's wildest and most natural places form part of an extensive system of strictly protected nature preserves (Ostergren 1998, Laletin et al. 2002) for which the Russian people are only now beginning to realize the wilderness values (Ostergren and Hollenhorst 2000).

In Iceland, recent legislation has defined wilderness and instructed regional planning efforts to consider recommendations of areas to be so protected
(Thórhallsdóttir 2002). In Sweden, Norway, and Greenland, although there are no officially protected wilderness lands or water, the term "wilderness" is commonly used to describe the most remote, natural places in these countries (Husby and Henry 1995).

Increasingly, natural and social scientists, communities, policy makers and resource managers are being confronted with issues that revolve around how "wilderness" should be used and, ultimately, valued as a component of the local, regional, and global culture. Generalized statements of the meaning and values of wilderness are less useful than providing in-depth understanding of values to specific social groups. This is mainly because the physical and ethereal qualities of wilderness vary too greatly to be discussed as a general concept (Watson et al. 2001).

Research in the USA on wilderness and wilderness values has mostly ignored the issue of indigenous peoples' subsistence uses on lands protected as wilderness (e.g., Cordell et al. 1998), although some literature has highlighted the history of the relationship 
between native people and public lands management agencies (e.g., Keller and Turek 1998) and the relationship between native people and nature in general (e.g., Carlson 1998). Wilderness research has progressed, however, from early studies in the 1960s that focused almost entirely on recreational uses of wilderness to more recent investigations of societal values (Wright 2000). Still, very little research has been conducted on the interaction between subsistence uses and other wilderness uses (Dear, in press) or the values associated with the relationship between wilderness and indigenous people. Use of wilderness by indigenous people for traditional values has been treated more as a special provision, or nonconforming use, because it does not conform to the wilderness ideal as presented in Euro-American philosophy. Traditional recreation motivation research and recreation conflict research have provided little insight into the broad array of value orientations held by the variety of stakeholders toward northern wilderness resources (Watson 1995, Kajala and Watson 1997).

Although the Wilderness Act did not specifically allow for subsistence uses in wilderness, the Alaska National Interest Lands Conservation Act (ANILCA) of 1980 did address the issue for those areas set aside as wilderness in Alaska. Through this one piece of legislation, approximately 56 million acres (22.6 million hectares) of Alaska public lands was added to the National Wilderness Preservation System. Provisions were specific: allow continuance of subsistence hunting and gathering in recognition of the special relationship between rural Alaskans and public lands in Alaska. Historic uses, such as snowmobiles, motorboats, aircraft, and temporary fishing and hunting camps, were also specifically allowed.

There is a continued need to understand how wilderness designation interacts with these and other indigenous activities in wildlands and the meanings attached to them. Recent attention drawn to the Arctic National Wildlife Refuge by efforts to increase oil and gas exploration there caused some interior Alaska native people to conclude that extending wilderness protection to these lands would not only meet the purposes set out in the U. S. Wilderness Act of 1964 and provide assurance that ANILCA purposes are met for subsistence, but would also help protect the role of the caribou in maintaining the identity of some native people (James 2001). The role of wilderness in protecting traditional relationships has not been fully explored (Huntington 2002) although there is a great deal of literature on how traditional ecological knowledge (TEK) can assist efforts to protect specific endangered species. Similarly, the role of TEK in wilderness stewardship, beyond species protection, has not been adequately addressed (Alessa and Watson 2002). The purpose of this paper is to illustrate the progression of conceptual thinking about wilderness, from mostly a recreation resource, to a more integrated approach bringing together recreation and ecological science issues to establish direction for monitoring and management, and, most recently, to a more holistic approach in the circumpolar north that acknowledges additional human-oriented values such as protection and restoration of traditional relationships with nature.

\section{TRADITIONAL ECOLOGICAL KNOWLEDGE AND WILDERNESS}

Traditional ecological knowledge is described by Huntington (2000) as the knowledge and insights acquired through extensive observation of an area or species. TEK can be used to understand and predict environmental events upon which the livelihood or even survival of individuals depend. Interest in TEK has been growing in recent years, partly in recognition that such knowledge can contribute to the conservation of biodiversity, rare species, and ecological processes (Gadgil et al. 1993, Berkes et al. 2000). Although the value of TEK in scientific research, impact assessment, and conservation monitoring has become more apparent and accepted, wider application of TEK-derived information remains elusive (Huntington 2000). The relationship between TEK and wilderness protection in the circumpolar north has been poorly described (Huntington 2002).

Many aboriginal people, including those in the arctic north, experience the environment as a whole; all of the parts are interrelated. People, animals, plants, landforms, and energy sources are not separate. Rather, they are all linked to each other and to local places through cultural traditions and interactive relationships (Turner et al. 2000). TEK is the application of the evolving knowledge accumulated about these relationships. The concept of knowledge developed through traditional relationships with nature can be expanded to TEKW (wisdom), recognizing the holistic aspect of TEK and that it is not easily subject to fragmentation (Turner et al. 2000). TEKW acknowledges that there is more than simply quantitative descriptions of these relationships; there is also wisdom acquired through understanding and maintaining these relationships in a complex system. More than any other single concept, the notion of 
respect for all lifeforms and the land itself is believed to characterize North American indigenous belief systems (Turner et al. 2000). Turner et al. (2000) suggest that at least part of native peoples' caring for their lands and resources relates directly to the wisdom of acknowledging the spirituality and influential powers in all things, including the earth.

Indigenous cultures of North America commonly include humans as integral to the community of nature. To many indigenous people, humans are part of the natural world; they are related to all other entities. In addition, indigenous people believe that the complex interactions that result from this relationship enhance and preserve the ecosystem. This concept of kincentricity with the natural world is referred to as kincentric ecology (Salmon 2000). Throughout time, people have pruned, harvested, gathered, cultivated, transplanted, propagated, sowed, burned, and weeded to increase chances of human survival (Martinez 1993). When ecologists, land managers, environmentalists, and conservationists speak and write about endangered species and their potential loss, however, they rarely place emphasis on the potential loss to human cultures that can arise from changing these ancient relationships (Salmon 2000).

In contrast to western philosophy, TEK assumes that humans are, and always will be, connected to the natural world, and that there is no such thing as nature that exists independent of humans and their activities (Pierotti and Wildcat 1997). According to Pierotti and Wildcat (1997), TEK promotes 1) respect for nonhuman entities as individuals, 2) recognition of bonds between humans and nonhumans, including incorporation of nonhumans into ethical codes of behavior, 3) appreciation of the importance of local places, and 4) recognition of humans as part of the ecological system, rather than as separate from and defining the existence of that system. As a result of these connections with the nonhuman world, native peoples do not think of nature as wilderness but as home (Pierotti and Wildcat 2000). TEK, however, represents a constantly evolving way of thinking about this home. The essence of traditional beliefs is that these relationships with nature have existed long enough for long-range consequences to affect them and to foresee the effects of potential changes (Pierotti and Wildcat 2000).

What began in the late $19^{\text {th }}$ and early $20^{\text {th }}$ centuries in the United States as an effort to save some remnants of the cultural (dominant European pioneer immigrant culture) and natural landscape as "wilderness," has spread to a worldwide movement (Martin and Watson 2002). There are many ways wilderness is protected today, including setting aside some private holdings; state, provincial, and national legislation; local, regional, and national land management agency policies; collaborative, co-management initiatives among tribal and other government interests; and nongovernmental organization actions. And wilderness is established for many reasons.

A definition that mostly focuses on the physical aspects of wilderness has been accepted by the World Conservation Union (IUCN): "large areas of unmodified or slightly modified land and/or sea, retaining its natural character and influence, which is protected and managed so as to preserve its natural condition." The stated objectives are broad and begin to address some of the reasons for wilderness protection, extending from 1) enjoyment by future generations of areas that are relatively undisturbed by humans, 2) maintenance of natural attributes and qualities, and 3) provision of appropriate public access for physical and spiritual well-being of visitors, to 4) enabling indigenous communities to continue living at low density, and in balance with available resources.

Somewhat in contrast to this international definition and North American indigenous cultural traditions, wilderness in the U. S. was established as a system of areas, defined in the Wilderness Act as areas where the earth and its community of life are untrammeled by man, where man himself is a visitor who does not remain. "Untrammeled" was included in this definition to mean "not subject to human controls and manipulations that hamper the free play of natural forces" (Hendee et al. 1990). Watson and Williams (1995) suggested that the American idea of wilderness (at least as codified in the Wilderness Act) as an area where "man himself is a visitor who does not remain" must be examined closely. We need to better understand the Euro-centric origin of this concept, in contrast to the indigenous meanings of the landscapes we are calling wilderness. Although Hendee et al. (1990) expressed the opinion that solitude is the single greatest concern to protecting wilderness experiences in the U. S., wilderness research and international collaboration have brought us to a more broad conceptualization of the human values and issues associated with wilderness protection today. 


\section{EVOLVING CONCEPTUAL APPROACHES TO WILDERNESS STEWARDSHIP}

The Limits of Acceptable Change (LAC) (Stankey et al. 1985) process has become widely used as a wilderness planning tool. Developed from a conceptual base in the early 1970s (Frissell and Stankey 1972), LAC guides those involved in wilderness management planning through a process that includes definition of recreational issues, decisions about the range of recreation opportunities a wilderness will provide, selection of relevant condition indicators, inventory of conditions, establishment of limits to allowable levels of impact, and monitoring to determine trends and trigger management actions.
The LAC process evolved from years of research conducted to understand relationships between recreational use (amount and type) and impacts to both the physical environment and human experiences within wilderness. Previous research by Stankey (e.g., 1980), Cole (e.g., 1981), and others provided the basis for understanding relationships between recreational use and impacts (mostly to soils, vegetation, and visitor satisfaction). The LAC process was developed explicitly to define the compromise between protection of the resource, visitor experiences, and the threat imposed by recreational use (Cole and Stankey 1997).

Fig. 1. The range of values and factors of influence associated with wilderness protection and restoration in the circumpolar north (from Alessa and Watson 2002)

INFLUENCING FACTORS (CONSTRAINTS \& CONTRIBUTORS)

\begin{tabular}{|c|c|c|c|c|c|c|c|c|c|c|c|c|c|c|c|c|c|}
\hline $\begin{array}{l}\text { WhLDERNASS } \\
\text { TALUES }\end{array}$ & $\begin{array}{l}\text { Collaborative } \\
\text { planning and } \\
\text { muatagethent }\end{array}$ & \begin{tabular}{|l|} 
Scientifific \\
studies
\end{tabular} & \begin{tabular}{|l} 
Political \\
conflict
\end{tabular} & \begin{tabular}{|l|}
$\begin{array}{l}\text { Hature } \\
\text { toutissm }\end{array}$ \\
\end{tabular} & \begin{tabular}{|l|} 
Worth- \\
South \\
tegionalisth
\end{tabular} & \begin{tabular}{|l|} 
Appreciation \\
of "sother" \\
otietrtations
\end{tabular} & Globalization & \begin{tabular}{|l|} 
Energy \\
explotation \\
and \\
development.
\end{tabular} & \begin{tabular}{|l|}
$\begin{array}{l}\text { Heavy } \\
\text { industry } \\
\text { developinent }\end{array}$ \\
\end{tabular} & \begin{tabular}{|l|} 
Fragmentation \\
of enosystems
\end{tabular} & \begin{tabular}{|l|} 
Traditional \\
/historical \\
uses
\end{tabular} & Conmerccialization & \begin{tabular}{|l} 
Funding \& \\
techrical \\
suppost
\end{tabular} & \begin{tabular}{|l|} 
Leadership \\
in \\
cotruturitities
\end{tabular} & $\begin{array}{l}\text { Fragility of } \\
\text { ecosystems }\end{array}$ & $\begin{array}{l}\text { Poot recovery } \\
\text { from human } \\
\text { distutbance }\end{array}$ & $\begin{array}{l}\text { Poaching } \\
\text { and other } \\
\text { illegal } \\
\text { violations }\end{array}$ \\
\hline \multicolumn{18}{|l|}{ Watershed protection } \\
\hline \multicolumn{18}{|l|}{ Cultural identityy } \\
\hline \multicolumn{18}{|l|}{ S̄piritzal inspiration } \\
\hline \multicolumn{18}{|l|}{ Education } \\
\hline \multicolumn{18}{|l|}{ Economic well-being } \\
\hline \multicolumn{18}{|l|}{$\begin{array}{l}\text { Natural biological } \\
\text { diversity }\end{array}$} \\
\hline \multicolumn{18}{|l|}{ Scientific knowledge } \\
\hline \multicolumn{18}{|l|}{$\begin{array}{l}\text { Protection of rare } \\
\text { objects }\end{array}$} \\
\hline \multicolumn{18}{|l|}{$\begin{array}{l}\text { Protection of } \\
\text { continuous of layge } \\
\text { ateas and } \\
\text { populations }\end{array}$} \\
\hline \multicolumn{18}{|l|}{$\begin{array}{l}\text { Protection of objects } \\
\text { of epistennological } \\
\text { significance }\end{array}$} \\
\hline \multicolumn{18}{|l|}{$\begin{array}{l}\text { Fristine (1ack of } \\
\text { hunthat intipact) }\end{array}$} \\
\hline \multicolumn{18}{|l|}{$\begin{array}{l}\text { Protection of objects } \\
\text { of international } \\
\text { significance }\end{array}$} \\
\hline \multicolumn{18}{|l|}{ Geological divessity } \\
\hline \multicolumn{18}{|l|}{ Scenic diversity } \\
\hline \multicolumn{18}{|l|}{$\begin{array}{l}\text { Lack of technological } \\
\text { advantage }\end{array}$} \\
\hline \multicolumn{18}{|l|}{ Sustainable lifestyles } \\
\hline \multicolumn{18}{|l|}{$\begin{array}{l}\text { Traditional ecological } \\
\text { knowledge }\end{array}$} \\
\hline \multicolumn{18}{|l|}{$\begin{array}{l}\text { Aesthetic/experiential } \\
\text { frecteation }\end{array}$} \\
\hline & & & & & & & & & & & & & & & & & \\
\hline Harvesting for spott & & & & & & & & & & & & & & & & & \\
\hline
\end{tabular}

In the 1990s, however, an expanded perception of wilderness attributes and threats led to attempts to define a wider range of indicators corresponding to a wider range of threats- beyond recreation (Watson and Cole 1992, Cole and Stankey 1997). Landres et al. (1994), recommending a strategy for development of monitoring protocols for wilderness, proposed an expanded set of matrices that should guide monitoring logic, including an expanded set of attributes of wilderness character and a range of potential threats to those attributes. Assuming an essential goal of wilderness management is to protect the wilderness resource from forces that can cause unnatural change in its character, forces of change were defined as internal and external to the wilderness, activities or the indirect effects of activities, and include management 
actions as potential threats to some attributes. Attributes of wilderness character needing protection include ecological components and processes, cultural sites, and human experiences that depend on wilderness character. It was suggested that the resulting matrix defined the known range of potential impacts and provided an organizational framework for monitoring and understanding trends in wilderness conditions and threats to those conditions.

By the turn of the century, however, cooperating scientists in the circumpolar north were working to expand and adapt this matrix approach to define the unique values of northern wilderness and identify major potential factors of influence (Watson et al. 2002). Some of the most significant pressures on wild places in the arctic north include pressures for economic development, oil and gas exploration and extraction, development of geothermal energy sources, development of heavy industry close to energy sources, and lack of appreciation for "other" orientations toward wilderness resources by interested parties (Alessa and Watson 2002). Alessa and Watson (2002) have summarized the range of values and factors of influence (both constraining and contributing forces) believed to be the most important when making decisions about wilderness protection, restoration, or development in the north (Fig. 1).

This matrix currently includes 19 different values that are ascribed to circumpolar north wilderness. Some values may be particularly important to specific cultures or stakeholder groups. Certain groups may place strong weight on some of these values for a single place and thereby influence arguments on which areas to protect as wilderness. There is not necessarily agreement, even among the countries of the circumpolar north or among stakeholder groups for a single area, about the most important values to protect, but the process of understanding these unique orientations toward the wilderness resource needs a common "framework" to guide discussion and knowledge building.

The columns of this matrix represent the factors that are believed to influence realization of the values listed in the rows. Each cell of the matrix indicates an interaction between an influencing factor (sometimes a constraining influence and sometimes a contributing factor) and a specific value. This matrix not only illustrates the unique set of values that are associated with circumpolar north wilderness, but also provides a framework for moving across the set of factors of influence in a way that increases understanding of a particular value, increases understanding of the role wilderness protection and restoration would play in providing that value, and highlights knowledge gaps.

\section{CONSIDERING THE RELATIONSHIP BETWEEN TEK AND POTENTIAL FACTORS OF INFLUENCE}

Those most constraining influences on the protection, restoration, and continuity of TEK that could be mitigated through wilderness protection might be political conflict, nature tourism, north-south regionalism, globalization, energy exploration and development, heavy industry development, fragmentation of ecosystems, commercialization, poor recovery from human disturbance, and poaching and other illegal violations.

\section{Political conflict}

Gladden (2002) suggests that analyzing the mixed currents of scientific, economic, ethnic, geographic, and historical values of wilderness communities of interest can help managers better anticipate and address political conflict, thereby protecting or restoring the broad set of values associated with wilderness. Gladden specifically advocates a discourse across the arctic countries on how TEK should be incorporated into a more unified wilderness idea for the cultures there. Rural residents in general should be motivated to maintain the natural integrity of a land base so that it can produce wildlife and other resources to meet their economic and cultural needs. Knowing, caring for, and respecting arctic lands provides rewards that are sustainable over a long period of time. Moving toward unified protection of the complex relationships within arctic ecosystems without political conflict, may best be served by wilderness designation.

The U. S. wilderness concept evolved with a strong link to cultural identity. The wilderness philosophers of the USA, including Muir, Leopold, and Marshall, commonly pointed out the role of wilderness in the development of the Euro-American identity. It is easy to see how discussions about meanings associated with wilderness could produce currents of political conflict. Different cultures may easily hold different values for the same resource. This conflict can threaten wilderness protection through lack of consensus on management goals and, therefore, threaten the cultural meanings held by all people. With a dominant Eurocentric population in most circumpolar north countries, 
this political conflict is most threatening to indigenous people and the values they place on traditional lifestyles and continuity of TEK.

\section{Nature tourism}

Interest in tourism to northern countries and Alaska is growing. Tourists to Greenland increased from 3500 in 1992 to 31,351 in 2000 (Kaae 2002). Tourism statistics in Iceland show nearly a $100 \%$ growth from 1990 to 1999 . Within another 10 to 15 years, the total annual number of foreign tourists to Iceland is expected to reach one million (Gunnarsson and Gunnarsson 2002). Although Alaska is not on the "top 10 " list of ecotourism destinations yet, due to remoteness, cost of travel, and a relatively underdeveloped tourism product, visitation has still been growing at about 4.5\% annually since 1995 (Faye 2001). There is great hope that nature tourism will contribute to prosperity in depressed rural economies of the north, but there is also fear that increased numbers of tourists, seeking unique experiences in the arctic north, will lead to increasingly crowded conditions, greater impact on the environment and cultural values, and increased constraints on realization of traditional values. Wilderness is often used as an attractant in tourism promotion, and sometimes native cultures are exploited for financial gain (Saarinen 2001), e.g., as in some U. S. National Parks (Keller and Turek 1998). Tourism management strategies and promotion can influence realization of traditional values. Greater protection of these values is necessary and achievable through priority focus on wilderness values.

\section{North-south regionalism}

Typically, circumpolar north wilderness is remote from population centers. Alaska, the largest of the 50 states in the USA, has one of the smallest populations and by far the lowest population density through much of the state. Over half of the 105 million acres of wilderness in the U. S. National Wilderness Preservation System is located in Alaska. In Finland, also, all of the legislatively protected wilderness units are above the Arctic Circle, but most of the population is in the south. Greenland's home-rule government (since 1979) is taking strides to exert more authority over important issues, although they remain closely linked to Denmark in many influential ways. Most wilderness resources are far removed in the north, away from legislative centers and the population, yet located in regions with high proportions of indigenous people. Without strong insistence or legislative influence and other protection strategies, the traditional relationships to these places will not be valued and protected by the majority, distant population.

\section{Globalization}

Williams (2002) points out that globalization has the effect of amplifying the importance of traditional forms of nature contact for those cultures that see it as part of their identity. However, globalization increases access to wilderness by distant people and this could destabilize "traditional" meanings and intensify conflict (Williams 2002). Protecting places as wilderness may be a significant means of protecting traditional lifestyles in a global world. Alternatively, as contended by Williams, the threat of globalization is that the deep meanings attached to wilderness can get lost and these spaces become segmented by modernity and thereby divested of traditional meanings.

Alaska was only the $49^{\text {th }}$ area to become a state in the USA. It is still relatively new to statehood, still struggling for identity as part of a larger nation. Finland, as a new member of the European Union, is also struggling to merge a historic set of values with an extended identity. The long-term effects of globalization and technological advances suggest strong influences on evolving native, remote cultures and the environment in which they live.

\section{Energy exploration and development}

In the western Siberian Arctic, as in Alaska, Canada, and Iceland, intensive technological invasion connected with oil and gas exploration has caused dramatic change in arctic ecosystems (Khitun and Rebristaya 2002). Not only is biodiversity threatened in many places, but so are the cultural and aesthetic values of these northern places. The number of tourists visiting Iceland each year (approximately 303,000) recently exceeded the total population of the country. An overwhelming majority of these visitors oppose energy-related development of the unique Highland Region of the country (Gunnarsson and Gunnarsson 2002). The preference of residents and visitors alike is to keep the landscape as unspoiled as it is today. Wilderness protection generally has excluded energy development actions elsewhere in the world. 


\section{Heavy industry development}

In an effort to realize revenue from development of energy-demanding industries, the government of Iceland is trying to attract investors for aluminum and other types of smelters (Gunnarsson and Gunnarsson 2002). Much of the energy supply for this industry is located in some of the most pristine areas of the country. This development could have devastating effects on the geological and biological diversity of the Central Highland Region of the country. In the USA, wilderness protection extends to protection of airsheds, with substantial influence on neighboring industry with air-pollution potential. Air pollution and subsequent impacts on vegetation and aesthetics are real threats to a broad range of wilderness values, including those traditional values held by indigenous people. A well-remembered image shown on American television in the 1980s was that of an American Indian man responding to air and water pollution with tears and sadness. Collective efforts to mitigate off-site pollution sources could hinge on wilderness protection, given the unquestioned impact these threats have on relationships between people and the environment.

\section{Fragmentation of ecosystems}

With expanding development, road building, and technological invasion, de facto wilderness is shrinking everywhere. Rapid fragmentation of the northern forests of Finland began as recently as the 1960 s as a result of development of an accessible market for pulpwood (Sippola 2002). The wilderness movement in Finland began in response to threats to accelerate removal of pristine forests in northern Lapland in the 1980s. The Finnish Wilderness Act, however, allows limited logging in six of the wilderness units, and road building for these timber activities threaten ecosystem function, even in the wilderness. Negotiation to allow this historic use of wilderness fails to protect the more holistic values associated with complete systems. The unmodified aspect of wilderness ecosystems and intent to retain or restore natural character and influence largely precludes roads and development that fragments systems. In Alaska, a proposed road through the Izembek National Wildlife Refuge Wilderness was shelved because of the unquestioned negative impact on wilderness character there, even though effects on sensitive flora and fauna species could have been mitigated by road design and construction methods (Clark 2000). Without intact ecosystems, relationships between the components of these ecosystems, including humans, are threatened.

\section{Commercialization}

Watson and Herath (1999) and Borrie et al. (2002) caution against the tendency for public land management to adopt a customer metaphor (Trainor and Norgaard 1999) and a focus on transactions rather than on retaining the relationships between the public and public lands. Public lands have evolved in response to a specific set of purposes, usually preceding development of an agency to ensure stewardship of the land and protection of those purposes. With trends toward charging fees for access to public lands and emphasis on supporting rural economies, there is a threat that these sometimes competing objectives may prevent realization of the original public purpose of public lands. Saarinen (2001) also cautions that ecotourism promotion and management can not only threaten the natural resources being commercialized, but also pose a threat to the cultural identity of native people.

\section{Poor recovery from human disturbance}

Plant communities of the western Siberian Arctic are extremely susceptible to disturbance caused by human activity (Khitun and Rebristaya 2002). Rates of recovery are slow. Five years after modern vehicle traffic in dwarf-birch-willow-graminoid-lichen-moss communities, Khitun and Rebristaya (2002) reported less than $5 \%$ vegetative recovery. When recovery does occur, it is usually at the expense of local flora.

Sustainable lifestyles in the arctic north imply an ethic of respect of the length of time needed for recovery from human impacts. Modern forms of conveyance have lasting impacts on soils and plants and such impacts must be controlled. Evolving traditions accommodate movement to more efficient means of transportation and harvesting by indigenous people, but the level of constraint allowable on natural processes and the impacts on traditional relationships must be acknowledged and limited.

\section{Poaching and other illegal violations}

Establishing wilderness to protect flora and fauna species or critical habitats from road building, development, and intensive human activities can create an intense problem with law enforcement. In Russia, mercenary-type poaching occurs regularly in protected 
areas of the Siberian Arctic (Laletin et al. 2002), yet low-paid inspectors report very few violations. There is substantial conflict between the local need for economic livelihood and nature protection objectives. Poaching also occurs for fossils and artifacts contained in burial sites. Wilderness protection makes it clear these activities are illegal, but enforcement by designated agencies seems to be difficult to achieve. If these resources provide important TEK values, local communities must become committed to protecting these ecosystems intact and be involved in protection of the resources there.

Those factors that might more likely contribute to the realization of the TEK value of wilderness include the movement toward more focused collaborative planning and management, scientific studies, appreciation of "other" orientations, traditional or historical uses, funding and technical support, and leadership in local communities.

\section{Collaborative planning and management}

Aboriginal and non-aboriginal differences in relationships with the wilderness resource can best be accommodated through collaborative relationships at the planning stage and continuing into management (Pfister 2002). Accommodating more than one worldview of these resources is a challenge, but repeated examples of success in collaboration suggest it is possible (Pfister 2002, Stadel et al. 2002). In the Northwest Territories of Canada, aboriginal people are recommending areas to be protected as wilderness based on the presence of significant past and present harvesting areas, spiritual sites and burial grounds, and traditional travel routes (Stadel et al. 2002). Documentation of traditional knowledge by recording oral histories and mapping is an essential part of the proposals for protecting these areas. Collaborative planning requires building trust (Borrie et al. 2002) and creativity to initiate stewardship practices that acknowledge multiple value orientations but that all benefit from protection of the wild and natural character of a place.

\section{Scientific studies}

Parsons (2000) has outlined common perceptions of the values of wilderness protection to science. Ecologists have long supported protecting large tracts of land for ecological investigation of natural processes, and "scientific use" was one of the public purposes listed in section 4(b) of the Wilderness Act as appropriate values to protect. Scientific studies can also be valuable to the protection of TEK values. Although little scientific investigation has occurred in wilderness (Franklin 1987, Parsons 2000), the scientific values are readily acknowledged and eagerly anticipated. Leopold (1966, p. 196) suggested that "A science of land health needs, first of all, a base datum of normality, a picture of how healthy land maintains itself as an organism." Leopold's proposed land ethic expanded the boundaries of the community of concern to include soils, waters, plants, and animals, or collectively: the land.

Wilderness is a place with all the pieces intact. Just as these intact systems offer opportunity for scientific investigation, they also provide opportunity for continued evolution of traditional relationships. TEK is not static, but the long history of association between people and the environment provides opportunity for continued growth in ability to anticipate reaction to human activity, whether by aboriginal or non-aboriginal visitors or managers. Wilderness protection concerns not just individual plants or animals, but also the relationship between humans and the land.

\section{Appreciation of "other" orientations}

There are different legal and philosophical orientations toward wilderness in the USA, as there are differences between countries. ANILCA, for example, extends legal orientation toward wilderness to include subsistence activities. This legal extension reflects the native perspective, described more as traditional relationships with these relatively intact, extensive ecosystems that are kept that way through wilderness protection. To native people, however, wilderness can be home, not a place without humans, confounding these multiple legal orientations.

There is also the orientation of the relatively uninformed. Today, there is increasing public attention on wild places of the U. S. arctic. Mass information campaigns surrounding recent debates in Congress have heightened awareness and appreciation of the threats associated with expanded mineral exploration and drilling in fragile portions of the arctic that have previously been protected. Relationships with these places are only now beginning to develop for much of the U. S. population.

Another orientation is that of the circumpolar north. Alaska, for example, is part of the USA, although it 
has a tremendous mix of indigenous and nonindigenous people and a rich history of association with Russia, Canada, and the USA. Not only is the history unique there, but the traditional relationships between people and the landscape are different from elsewhere in the USA, the fragility of the ecosystem is different, and the degree of completeness of ecosystems is different from much of the world. The orientation we need to be more aware of and appreciate is that of the circumpolar north. We need to have more sharing of information between scientists in this part of the world, positive communication and cooperation in education programs, and thus, greater appreciation of the meanings of the circumpolar north both to residents there as well as to the rest of the world.

\section{Traditional and historical uses}

Humans have co-evolved with the environment. The cultural landscape of the American wilderness that European pioneers found was one that had been influenced for thousands of years by the sustainable practices of the native people. The same is true in most of the circumpolar north countries, with the exception of Iceland, which had no indigenous population. North American people introduced disturbance in a variety of ways, including fire and soil disturbance, to affect the composition and structure of ecosystems in such a way as to sustain human life (Berkes et al. 2000). In this case, this particular historic use of nature is such an integral part of it that, although sometimes thought of as a constraint on existence of natural conditions, it actually can become the essential element of wildness, with humans at the center of a sustainable system, exercising respect and a wealth of historic knowledge to improve the chances of survival of the human species.

\section{Funding and technical support}

Prior to ANILCA in 1980, and the Finnish Wilderness Act in 1991, the lands that now enjoy the many benefits of wilderness protection were not protected for any specific set of purposes. Establishing wilderness protection with accompanying commitment by responsible management agencies provides the impetus for development of stewardship plans, collaborative involvement of interested parties, and long-term assurance of protection from development. It is argued that recognizing an area as wilderness, complete with establishment of boundaries, designating a name, and assigning the area to an administrative branch of the federal government in fact removes much of the wilderness character of the place. However, if we accept the fact that this evidence of geographical organization and social construction can carry a plurality of meanings (Williams 2002), the tensions (Glaspell 2002) and potential political conflict (Gladden 2002) emanating from the diversity of demands on such places can also be acknowledged and addressed.

\section{Leadership in local communities}

Kluwe (2002), based on research in Finland and Alaska on conflict between local and distant users of wilderness, recognizes that many of the values associated with traditional lifestyles depend only partially on access to the natural resources found in wilderness. Actual use of the raw resources, as well as retention and advancement of TEK, depends on leadership in local indigenous communities. Much as the U. S. Wilderness Act defines wilderness as providing opportunities for solitude, it also only provides opportunities for realizing the values associated with TEK.

\section{CONCLUSIONS}

In the past, and likely into the future, science-based policies have been heavily influenced by western folklore and beliefs (Marrow and Hensel 1992). Marrow and Hensel (1992) have described instances where Alaska natives have been pressured to defend practices in a manner congruent with approved patterns of western discourse and logic. The wilderness concept in the USA has been constructed within these western patterns of discourse and logic. The conceptualization of wilderness stewardship, however, has evolved since creation of the U. S. National Wilderness Preservation System, and the meaning of wilderness continues to evolve in the USA and other countries. A great deal of emphasis has been placed on understanding the impacts of recreational use and protection of solitude experiences, often to the exclusion of other threats, to the exclusion of a more broad range of values dependent upon wilderness systems, and to the exclusion of understanding those forces that may ultimately facilitate realization of these values. Stewardship roles are expanding to acknowledge a broad range of attributes of wilderness which give rise to a variety of values.

Some of the most serious threats to TEK values for wilderness places may be political conflict, north-south 
regionalism, globalization, and energy development pressures. Most of these involve the need for distant cultures and government organizations to better understand how these forces threaten traditional values. However, the most promising ways to protect these values reside in tendencies toward collaborative comanagement, building greater appreciation of "other" orientations toward wilderness resources, and opportunities for local community leadership to apply TEK to sustaining traditional lifestyles. All management and allocation decisions should be based on thorough consideration of these factors of influence, particularly on how actions to control or facilitate these factors of influence will affect TEK values.

An ongoing need in the allocation and management arena is to understand how wilderness and nonwilderness areas differ. In this paper, the difference is illustrated from a new perspective. TEK is a quantitative source of information that could probably be retained as a significant part of traditional lifestyles outside of wilderness, but the concept of TEKW clearly illustrates that the significance of TEK is the application to understanding and maintaining the relationship between the full community of human and nonhuman entities found in nature. Many native people want to preserve subsistence as a way of relating to the world and as an important component of identity (Marrow and Hensel 1992). By maintaining places where the dominant effect of human intervention is guided by respect and kincentric relationships, in effect we protect, or potentially restore, the dominant values associated with accumulation of traditional ecological knowledge. These values are unique to and dependent upon wilderness. In wilderness, it is wisdom that is sought, beyond specific knowledge. This wisdom will come from understanding and maintaining human relationships with wilderness, not specific elements within it.

Responses to this article can be read online at: http://www.consecol.org/vol//iss1/art2/responses/index.html

\section{LITERATURE CITED}

Alessa, L., and A. Watson. 2002. Growing pressures on circumpolar north wilderness. Pages 133-142 in A. Watson, L. Alessa, and J. Sproull, compilers. Wilderness in the circumpolar north: searching for compatibility in traditional, ecotourism, and ecological values. Proceedings RMRS-P-26. May 15-16, 2001. Anchorage, Alaska, USA. U. S. Department of Agriculture, Forest Service, Rocky Mountain Research Station, Ogden, Utah, USA.
Berkes, F., J. Colding, and C. Folke. 2000. Rediscovery of traditional ecological knowledge as adaptive management. Ecological Applications 10(5):1251-1262.

Borrie, W. T., N. Christensen, A. E. Watson, T. A. Miller, and D. W. McCollum. 2002. Public purpose recreation marketing: a focus on the relationships between the public and public lands. Journal of Park and Recreation Administration 20(2):49-68.

Carlson, P. H. 1998. The Plains Indians. Texas A \& M University Press, College Station, Texas, USA.

Clark, J. R. 2000. The value of wilderness to the U. S. National Wildlife Refuge System. International Journal of Wilderness 6(3):7-11.

Cole, D. N. 1981. Managing ecological impacts at wilderness campsites: an evaluation of techniques. Journal of Forestry 79(2):86-89.

Cole, D. N. 2000. Natural, wild, uncrowded, or free: which of these should wilderness be? International Journal of Wilderness 6(2):5-8.

Cole, D. N., and G. H. Stankey. 1997. Historical development of limits of acceptable change: conceptual clarifications and possible extensions. Pages 5-9 in S. F. $\mathrm{McCool}$ and D. N. Cole, compilers. Proceedings. Limits of acceptable change and related planning processes: progress and future directions. May 20-22, 1997. Missoula, Montana, USA. Gen. Tech. Rep. INT-GTR-371. U. S. Department of Agriculture, Forest Service, Rocky Mountain Research Station, Ogden, Utah, USA.

Cordell, H. K., M. A. Tarrant, B. L. McDonald, and J. C. Bergstrom. 1998. How the public views wilderness: more results from the USA survey on recreation and the environment. International Journal of Wilderness 4(3): 28 31.

Dear, C. In press. Recreationists' conceptualization of interactions with subsistence in Gates of the Arctic National Park and Preserve, Alaska. In A. Watson and J. Sproull, compilers. Seventh World Wilderness Congress Symposium: Science and stewardship to protect and sustain wilderness values. November 2-8, 2001, Port Elizabeth, South Africa. Proceedings RMRS-P-000. U. S. Department of Agriculture, Forest Service, Rocky Mountain Research Station, Ogden, Utah, USA.

Faye, G. 2001. The effects of federal government wilderness stewardship policies on tourism activities in Alaska. Presented at Wilderness in the circumpolar north: searching for compatibility in traditional, ecotourism, and ecological values. May 15-16, 2001. Anchorage, Alaska, USA.

Franklin, J. F. 1987. Scientific use of wilderness. Pages 42-46 in R. C. Lucas, compiler. Proceedings of the National Wilderness Research Conference. Issues, state-of- 
knowledge, future directions. U. S. Department of Agriculture, Forest Service, General Technical Report INT220. Ogden, Utah, USA.

Frissell, S. S., and G. H. Stankey. 1972. Wilderness environmental quality: search for social and ecological harmony. Pages 170-183 in Proceedings of the Society of American Foresters. Hot Springs, Arkansas, USA.

Gadgil, M., F. Berkes, and C. Folke. 1993. Indigenous knowledge for biodiversity conservation. Ambio 22:151156.

Gladden, J. N. 2002. The origin of political conflict in Arctic wilderness areas. Pages 7-14 in A. Watson, L. Alessa, and J. Sproull, compilers. Wilderness in the circumpolar north: searching for compatibility in traditional, ecotourism, and ecological values. Proceedings RMRS-P-26. May 15-16, 2001. Anchorage, Alaska, USA. U. S. Department of Agriculture, Forest Service, Rocky Mountain Research Station, Ogden, Utah, USA.

Glaspell, B. S. 2002. Minding the meaning of wilderness: investigating the tensions and complexities inherent in wilderness visitors' experience narratives. Dissertation, University of Montana, School of Forestry, Missoula, Montana, USA.

Gunnarsson, B., and M. Gunnarsson. 2002. Iceland's central highlands: nature conservation, ecotourism and energy resource utilization. Pages 54-63 in A. Watson, L. Alessa, and J. Sproull, compilers. Wilderness in the circumpolar north: searching for compatibility in traditional, ecotourism, and ecological values. May 15-16, 2001. Anchorage, Alaska, USA. Proceedings RMRS-P-26. U. S. Department of Agriculture, Forest Service, Rocky Mountain Research Station, Ogden, Utah, USA.

Hendee, J. C., G. H. Stankey, and R. C. Lucas. 1990. Wilderness management. Second edition. North American Press, Golden, Colorado, USA.

Huntington, H. 2002. Can traditional ecological knowledge and wilderness benefit one another? Pages 64-68 in A. Watson, L. Alessa, and J. Sproull, compilers. Wilderness in the circumpolar north: searching for compatibility in traditional, ecotourism, and ecological values. May 15-16, 2001. Anchorage, Alaska, USA. Proceedings RMRS-P-26. U. S. Department of Agriculture, Forest Service, Rocky Mountain Research Station, Ogden, Utah, USA.

Huntington, H. P. 2000. Using traditional ecological knowledge in science: methods and applications. Ecological Applications 10(5):1270-1274.

Husby, E., and D. Henry. 1995. Wilderness quality mapping in the Euro-Arctic Barents region. In A.-L. Sippola, P. Alaraudanjoki, B. Forbes, and V. Hallikainen, editors. 1995. Northern wilderness areas: ecology, sustainability, values. Arctic Centre Publications 7.
James, S. 2001. We are the ones who have everything to lose. Pages 3-5 in H. Lentfer and C. Servid, compilers. 2001. Arctic refuge: a circle of testimony. Milkweed Editions, Minneapolis, Minnesota, USA.

Kaae, B. C. 2002. Nature and tourism in Greenland. Pages 43-53 in A. Watson, L. Alessa, and J. Sproull, compilers. Wilderness in the circumpolar north: searching for compatibility in traditional, ecotourism, and ecological values. May 15-16, 2001. Anchorage, Alaska, USA. Proceedings RMRS-P-26. U. S. Department of Agriculture, Forest Service, Rocky Mountain Research Station, Ogden, Utah, USA.

Kajala, L., and A. Watson. 1997. Wilderness-different cultures, different research needs: comparing conflict research needs in Finland and the United States. International Journal of Wilderness 3(2):33-36.

Keller, R. H., and M. F. Turek. 1998. American Indians and National Parks. The University of Arizona Press, Tucson, Arizona, USA.

Khitun, O., and O. Rebristaya. 2002. Anthropogenic impacts on habitat structure and species richness in the West Siberian Arctic. Pages 85-95 in A. Watson, L. Alessa, and J. Sproull, compilers. Wilderness in the circumpolar north: searching for compatibility in traditional, ecotourism, and ecological values. May 15-16, 2001. Anchorage, Alaska, USA. Proceedings RMRS-P-26. U. S. Department of Agriculture, Forest Service, Rocky Mountain Research Station, Ogden, Utah, USA.

Kluwe, J. 2002. Understanding wilderness land use conflicts in Alaska and Finland. Dissertation. University of Idaho, Moscow, Idaho, USA.

Laletin, A. P., D. V. Vladyshevsk, and A. D. Vladyshevsky. 2002. Protected areas of the central Siberian Arctic: history, status and prospects. Pages 15-19 in A. Watson, L. Alessa, and J. Sproull, compilers. Wilderness in the circumpolar north: searching for compatibility in traditional, ecotourism, and ecological values. May 15-16, 2001. Anchorage, Alaska, USA. Proceedings RMRS-P-26. U. S. Department of Agriculture, Forest Service, Rocky Mountain Research Station, Ogden, Utah, USA.

Landres, P., M. W. Brunson, and L. Merigliano. 2000. Naturalness and wildness: the dilemma and irony of ecological restoration in wilderness. Wild Earth (winter 2000/2001):77-82.

Landres, P., D. Cole, and A. Watson. 1994. A monitoring strategy for the National Wilderness Preservation System. Pages 192-197 in J. C. Hendee and V. G. Martin, editors. International wilderness allocation, management, and research. International Wilderness Leadership (WILD) Foundation, Fort Collins, Colorado, USA.

Leopold, A. 1966. A Sand County almanac. Ballantine Books, New York, New York, USA. 
Marrow, P., and C. Hensel. 1992. Hidden dissension: minority-majority relationships and the use of contested terminology. Arctic Anthropology 29(1):38-53.

Martin, V., and A. E. Watson. 2002. International wilderness protection. Pages 49-99 in J. C. Hendee and C. Dawson, editors. Wilderness Management. Third edition. Fulcrum Publishing, Golden, Colorado, USA.

Martinez, D. 1993. Managing a precarious balance: wilderness versus sustainable forestry. Winds of Change 8(3):23-28.

Ostergren, D. 1998. System in peril: a case study of six Siberian nature preserves. International Journal of Wilderness 4(3):12-17.

Ostergren, D., and S. Hollenhorst. 2000. Converging protected area policy: a case study of the Russian zapovednik (strict nature preserve) and American wilderness systems. Pages 3-8 In A. E. Watson, G. H. Aplet, and J. C. Hendee, compilers. Personal, societal, and ecological values of wilderness. Sixth World Wilderness Congress proceedings on research, management, and allocation, Volume II. October 24-29, 1998. Bangalore, India. Proc. RMRS-P-14. U. S. Department of Agriculture, Forest Service, Rocky Mountain Research Station, Ogden, Utah, USA.

Parsons, D. J. 2000. The challenge of scientific activities in wilderness. Pages 252-257 in S. F. McCool, D. N. Cole, W. T. Borrie, and J. O'Loughlin, compilers. Wilderness science in a time of change conference, Volume 3: Wilderness as a place for scientific inquiry. May 23-27, 1999. Missoula, Montana, USA. Proceedings RMRS-P-15-VOL-3. U. S. Department of Agriculture, Forest Service, Rocky Mountain Research Station, Ogden, Utah, USA.

Pfister, R. E. 2002. Collaboration across cultural boundaries to protect wild places: the British Columbia experience. Pages 27-35 in A. Watson, L. Alessa, and J. Sproull, compilers. Wilderness in the circumpolar north: searching for compatibility in traditional, ecotourism, and ecological values. May 15-16, 2001. Anchorage, Alaska, USA. Proceedings RMRS-P-26. U. S. Department of Agriculture, Forest Service, Rocky Mountain Research Station, Ogden, Utah, USA.

Pierotti, R., and D. Wildcat. 1997. Evolution, creation, and native traditions. Winds of Change 12(2):73-77.

Pierotti, R., and D. Wildcat. 2000. Traditional ecological knowledge: the third alternative (commentary). Ecological Applications 10(5):1333-1340.

Saarinen, J. 2001. The transformation of a tourist destination: theory and case studies on the production of local geographies in tourism in Finnish Lapland. Nordia Geographical Publication 30(1):1-105.

Salmon, E. 2000. Kinentric ecology: indigenous perceptions of the human-nature relationship. Ecological Applications 10(5):1327-1332.

Sippola, A. 2002. Biodiversity in Finnish wilderness areas: historical and cultural constraints to preserve species and habitats. Pages 75-84 in A. Watson, L. Alessa, and J. Sproull, compilers. Wilderness in the circumpolar north: searching for compatibility in traditional, ecotourism, and ecological values. May 15-16, 2001. Anchorage, Alaska, USA. Proceedings RMRS-P-26. U. S. Department of Agriculture, Forest Service, Rocky Mountain Research Station, Ogden, Utah, USA.

Stadel, A., R. Taniton, and H. Heder. 2002. The Northwest Territories protected areas strategy: how community values are shaping the protection of wild spaces and heritage places. Pages 20-26 in A. Watson, L. Alessa, and J. Sproull, compilers. Wilderness in the circumpolar north: searching for compatibility in traditional, ecotourism, and ecological values. May 15-16, 2001. Anchorage, Alaska, USA. Proceedings RMRS-P-26. U. S. Department of Agriculture, Forest Service, Rocky Mountain Research Station, Ogden, Utah, USA.

Stankey, G. H. 1980. A comparison of carrying capacity perceptions among visitors to two wildernesses. U. S. Department of Agriculture, Forest Service, Intermountain Forest and Range Experiment Station, Ogden, Utah, USA. Res. Pap. INT-242.

Stankey, G. H., D. N. Cole, R. C. Lucas, M.E. Petersen, and S. S. Frissell. 1985. The limits of acceptable change (LAC) system for wilderness planning. U. S. Department of Agriculture, Forest Service, Intermountain Forest and Range Experiment Station, Ogden, Utah, USA. Gen. Tech. Rep. INT-176.

Thórhallsdóttir, T. 2002. Evaluating nature and wilderness in Iceland. Pages 96-104 in A. Watson, L. Alessa, and J. Sproull, compilers. Wilderness in the circumpolar north: searching for compatibility in traditional, ecotourism, and ecological values. May 15-16, 2001. Anchorage, Alaska, USA. Proceedings RMRS-P-26. U. S. Department of Agriculture, Forest Service, Rocky Mountain Research Station, Ogden, Utah, USA.

Trainor, S. F., and R. B. Norgaard. 1999. Recreation fees in the context of wilderness values. Journal of Park and Recreation Administration 17(3):100-115.

Turner, N. J., M. B. Ignace, and R. Ignace. 2000. Traditional ecological knowledge and wisdom of aboriginal peoples in British Columbia. Ecological Applications 10(5):1275-1287.

Watson, A. E. 1995. An analysis of recent progress in recreation conflict research and perceptions of future challenges and opportunities. Leisure Sciences 17(3):235238 .

Watson, A., L. Alessa, and J. Sproull, compilers. 2002. 
Wilderness in the circumpolar north: searching for compatibility in traditional, ecotourism, and ecological values. May 15-16, 2001. Anchorage, AK. Proceedings RMRS-P-26. U. S. Department of Agriculture, Forest Service, Rocky Mountain Research Station, Ogden, Utah, USA.

Watson, A., L. Alessa, L., and D. Williams. 2001. Northern wilderness: searching for compatibility between traditional relationships with nature, ecotourism, and ecological protection. In Proceedings, Seventh Circumpolar University Co-operation Conference, Troms $\emptyset$, Norway, August 19-21, 2001. Centre for Sámi Studies, University of Tromsø.

Watson, A. E., and D. N. Cole. 1992. LAC indicators: an evaluation of progress and list of proposed indicators. In L. Merigliano, editor. 1992. Ideas for limits of acceptable change process. Book II: selected papers on wilderness management planning efforts and the LAC process. U. S. Department of Agriculture, Forest Service. Recreation, Cultural Resources and Wilderness Management Staff.

Watson, A. E., and G. Herath. 1999. Research implications of the theme issues "Recreation fees and pricing issues in the public sector" (Journal of Park and Recreation Administration) and "Societal response to recreation fees on public lands" (Journal of Leisure Research). Journal of Leisure Research 31(3):325-334.

Watson, A. E., and D. R. Williams. 1995. Priorities for human experience research in wilderness. Trends (Wilderness Research) 32(1):14-18.

Williams, D. R. 2002. The social construction of arctic wilderness: place meanings, value pluralism and globalization. Pages 120-132 in A. Watson, L. Alessa, and J. Sproull, compilers. Wilderness in the circumpolar north: searching for compatibility in traditional, ecotourism, and ecological values. May 15-16, 2001. Anchorage, Alaska, USA. Proceedings RMRS-P-26. U. S. Department of Agriculture, Forest Service, Rocky Mountain Research Station, Ogden, Utah, USA.

Wright, V. 2000. The Aldo Leopold Wilderness Research Institute: a national wilderness research program in support of wilderness management. Pages 260-268 in S. F. McCool, D. N. Cole, W. T. Borrie, and J. O'Loughlin, compilers. Wilderness science in a time of change conference. Volume 3: Wilderness as a place for scientific inquiry. May 23-27, 1999. Missoula, Montana, USA. Proceedings RMRS-P-15VOL-3. U. S. Department of Agriculture, Forest Service, Rocky Mountain Research Station, Ogden, Utah, USA. 